\title{
Uma revista de Direito Sanitário na Internet
}

\author{
A journal on Health Law in the internet
}

Cadernos Ibero-Americanos de Direito Sanitário / Cuadernos Iberoamericanos de Derecho Sanitario é uma publicação eletrônica bilíngue (português e espanhol), de acesso livre, destinada a difundir a produção acadêmica no campo do Direito Sanitário.

É uma publicação da Rede Ibero-Americana de Direito Sanitário, que congrega profissionais e instituições acadêmicas de Direito e de Saúde envolvidos com o estudo, o ensino e a pesquisa do Direito Sanitário na América Latina e na Península Ibérica, e dirige-se a professores, pesquisadores e estudantes de Direito, de Ciências da Saúde e de Ciências Sociais, operadores do Direito, profissionais de saúde e gestores de serviços e sistemas de saúde.

Seus objetivos são difundir e estimular o desenvolvimento do Direito Sanitário na região ibero-americana, divulgar a produção científica dos profissionais e instituições que compõem a Rede Ibero-Americana de Direito Sanitário e promover o debate dos grandes temas e dos principais desafios do Direito Sanitário contemporâneo.

Propõe-se a publicar resultados de pesquisas, artigos científicos, de revisão e de opinião, trabalhos doutrinários, jurisprudência comentada, análises de legislação sanitária e resenhas, sob o regime de double-blind peer review, de tal forma que se garanta qualidade à informação veiculada e à linha editorial da revista.

Os Cadernos pretendem constituir-se, assim, em um meio acessível, barato e eficiente de difundir informação jurídica e técnica de qualidade sobre Direito Sanitário - condição que encontramos na Internet. Por mais de um século, as revistas impressas constituíram o meio dominante de veiculação de conhecimento científico e jurídico em todo o mundo. Hoje, a Rede Mundial de Computadores desempenha esse papel, com idêntica - ou, possivelmente maior - efetividade e menores custos.

Para limitar ao mínimo possível barreiras tanto para a publicação quanto ao acesso, os materiais para publicação serão aceitos livres de taxas ou custos, tanto para seus autores quanto para suas instituições, e será dado livre acesso a eles, isto é, os números dos Cadernos e os materiais neles publicados estarão livremente disponíveis online para leitores em todo o mundo, sem restrições quanto à distribuição, download, impressão, cópia e uso legítimo da informação. 
Isso não quer dizer que sua edição e produção se farão sem custos. Os custos da editoria científica e da secretaria da Revista serão suportados pelo Programa de Direito Sanitário da Fundação Oswaldo Cruz (Prodisa/Fiocruz), ao mesmo tempo em que seu Corpo Editorial - Conselho Editorial e corpo de avaliadores, composto por membros da Rede, - contribui, sem remuneração, com seu trabalho.

Nesse sentido, os Cadernos nascem como um projeto cooperativo no âmbito da Rede Iberoamericana de Direito Sanitário, para oferecer novas ideias e informação de qualidade, e apoio à educação e à pesquisa no campo do Direito Sanitário na Região lberoamericana.

Por favor, divulgue os Cadernos entre seus colegas, alunos e amigos.

E publique, em suas páginas, sua produção científica.

Brasília, outubro de 2012.

\section{Editor Científico}

